\title{
FUZZY LOGIC CONTROLLER FOR SMART HOME LIGHTING CONTROL
}

\author{
I.B. Olenych \\ Ivan Franko National University of Lviv, Lviv, Ukraine
}

\begin{abstract}
Background. Modern high-tech automation systems are able to provide unmanned productive and efficient management of smart home functions. These systems should provide control of temperature, light level, humidity and air pollution for a comfortable stay in the building. In particular, fuzzy logic controller has the potential for application in intelligent systems of lighting control.
\end{abstract}

Objective.Te aim of the paper is to design the two-channel lighting control system in smart home that provides control of lighting source power and of their spectral characteristics.

Methods. The lighting control system is based on fuzzy inference and provides forming the base of fuzzy production rules, fuzzification of input values, aggregation of truth of sub conditions of each rule, activation of conclusions and defuzzification process that generates an output signal to control the smart home functional devices.

Results. The crisp values of light source power with different spectral characteristics and output signal that controls the transparency of windows have been obtained in result of representation of input data of different types using linguistic variables and fuzzy production rules for the current values of natural light and time of day. It is shown the possibility to change the sensitivity of the control systems in different ranges of illumination deviation from optimal values.

Conclusions. The lighting control method in buildings based on fuzzy logic controller enables to get the quantitative values of power of light sources with different spectral characteristics taking into account the individual characteristics of residents.

Keywords: lighting control; fuzzy logic controller; production rules; fuzzy sets; conclusions activation.

\section{Introduction}

The development of intelligent "smart home" systems is closely linked with state-of-the-art achievements of modern electrical engineering and information technology [1]. Modern high-tech building automation systems are able to provide unmanned productive and efficient management of all resources of working or residential buildings and to solve many domestic problems on its own [2-4]. Thanks to the coordinated management of all functions of smart building there are saved efforts, time and money of its inhabitants.

In addition, an important indicator of quality of buildings is the level of comfort, determined by compliance of values of basic parameters of apartment to optimum conditions of the human body in the system "human - residential environment". These parameters include temperature conditions, humidity and air pollution in the room, light level and so on.

Illumination control is one of the most requested features of intelligent smart house systems [5, 6]. Switching off unnecessary loads or shifting to low power consumption mode can significantly reduce energy costs. For a comfortable stay in the building it should provide control of not only power of lighting sources, but also of their spectral characteristics. In the daytime the "cold" light with color temperature of 4000-5500 K, which helps create working atmosphere in the room, is optimally combined with natural light. In the morning and evening a source of "warm" light with a color temperature of 2700-3500 K should be used, because it creates an atmosphere of coziness and comfort. Besides, on sunny days it is often necessary to reduce the illumination of buildings. Effective management of light permeability of windows is possible by using smart glasses containing electrochromic or liquid crystal material. A characteristic feature of these materials is the ability to reverse optical changes (appearance of color or changing one color to another one) under the influence of an electric current, and the degree of transparency can be controlled by the applied voltage [7-9].

Comprehensive coverage of different criteria of comfortable living involves the use of linguistic variables, which are close to spoken language by structure presentation, in information technologies of lighting control system of smart house. In this case it is advisable to use fuzzy modeling methods [10-12]. The theory of fuzzy sets makes it possible to apply linguistic description of complicated processes, to establish the correlation between concepts and implement a formal description of fuzzy rules in control systems [13-15].

In this paper the two-channel lighting control system in buildings based on fuzzy inference is proposed. It has been demonstrated that fuzzy logic controller provides 
control of not only power of lighting sources, but also of their spectral characteristics.

\section{Fuzzy inference system description}

Architecture of fuzzy logic controller, used in lighting control system, consists of input signal renderer (photoreceivers and timers), block of fuzzification, base of fuzzy production rules and block of defuzzification, which generates an output signal to lighting system control (Fig. 1).

Method of automatic lighting control in buildings, based on fuzzy logic controller, provides forming the base of fuzzy production rules $R^{(k)}$ as IF (condition) THEN (action), fuzzification of input values of light intensity, activation of conclusions, based on the found truth values of each condition of fuzzy production rules, and defuzzification process that generates an output signal to control the functional devices of lighting system.

Rules $R^{(k)}$ accumulate information of various origins, including experimental data, results of simulation and conclusions of experts. In general, the rules may include all possible combinations of terms for all input linguistic variables, combined by fuzzy logic operations.

\section{Design of fuzzy logic controller}

The algorithm of fuzzy inference, proposed by Mamdani [16], was used to implement lighting control systems of smart house. Base of fuzzy production rules $R^{(k)}$ has been formed for a system with two inputs and two outputs:

$$
\begin{gathered}
R^{(k)}: \text { IF } x_{1} \text { is } A_{1 k} \text { AND } x_{2} \text { is } A_{2 k} \text { THEN } y_{1} \text { is } G_{1 k}, \\
y_{2} \text { is } G_{2 k},
\end{gathered}
$$

where $k=1,2, \quad, n ; n$-number of rules; $x_{1} \in[0,350]$ and $x_{2} \in[6,22]$ - input variables that reflect illumination in lux and time of day, respectively; $y_{1}, y_{2}$ $\in[-1,1]$ - output variables that reflect the control signal of "cold" $S^{(C)}$ and "warm" $S^{(W)}$ light; $A_{i k}$ and $G_{j k}$ terms of input and output linguistic variables.

The base of fuzzy production rules of lighting control systems in buildings is given in Table 1 .

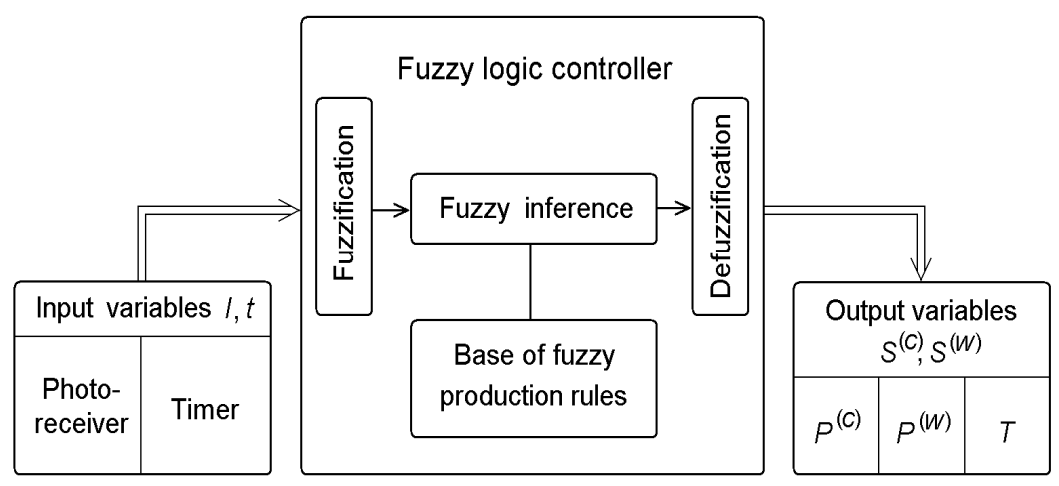

Fig. 1. Scheme of the process of lighting control based on fuzzy logic controller

Table 1. Base of fuzzy production rules of lighting control systems in buildings

\begin{tabular}{|c|c|c|c|c|c|}
\hline \multirow{2}{*}{$\begin{array}{c}\text { Time of } \\
\text { day }\end{array}$} & \multicolumn{5}{|c|}{ The intensity of natural light } \\
\cline { 2 - 6 } Morning & Very low & Low & Middle & High & Very high \\
\hline Day & $\begin{array}{c}S^{(C)}=0 \\
\text { Significantly } \\
\text { increase } S^{(W)}\end{array}$ & $\begin{array}{c}S^{(C)}=0 \\
\text { Increase } S^{(W)}\end{array}$ & $\begin{array}{c}S^{(C)}=0 \\
\text { Normal } S^{(W)}\end{array}$ & $\begin{array}{c}S^{(C)}=0 \\
\text { Decrease } S^{(W)}\end{array}$ & $\begin{array}{c}S^{(C)}=0 \\
\text { Significantly } \\
\text { decrease } S^{(W)}\end{array}$ \\
\hline Evening & $\begin{array}{c}\text { Significantly } \\
\text { increase } S^{(C)} \\
S^{(W)}=0\end{array}$ & $\begin{array}{c}\text { Increase } S^{(C)} \\
S^{(W)}=0\end{array}$ & $\begin{array}{c}\text { Normal } S^{(C)} \\
S^{(W)}=0\end{array}$ & $\begin{array}{c}\text { Decrease } S^{(C)} \\
S^{(W)}=0\end{array}$ & $\begin{array}{c}\text { Significantly } \\
\text { decrease } S^{(C)} \\
S^{(W)}=0\end{array}$ \\
\hline $\begin{array}{c}\text { Significantly } \\
\text { increase } S^{(W)}\end{array}$ & $\begin{array}{c}S^{(C)}=0 \\
\text { Increase } S^{(W)}\end{array}$ & $\begin{array}{c}S^{(C)}=0 \\
\text { Normal } S^{(W)}\end{array}$ & $\begin{array}{c}S^{(C)}=0 \\
\text { Decrease } S^{(W)}\end{array}$ & $\begin{array}{c}S^{(C)}=0 \\
\text { Significantly } \\
\text { decrease } S^{(W)}\end{array}$ \\
\hline
\end{tabular}


Membership functions of fuzzy sets describing "intensity of natural light" and "time of day" input variables and $S^{(C)}$ and $S^{(W)}$ output variables, were set by piecewise linear or spline functions (Fig. 2). Aggregation procedure for subconditions verity of each rule of the fuzzy inference system was carried out by the fuzzy conjunction operation AND, which was defined by an algebraic product of two fuzzy expressions degree of verity.

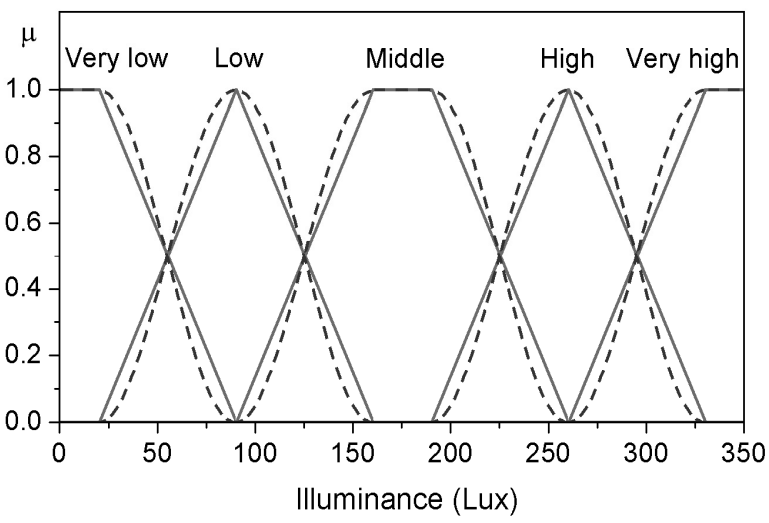

a)

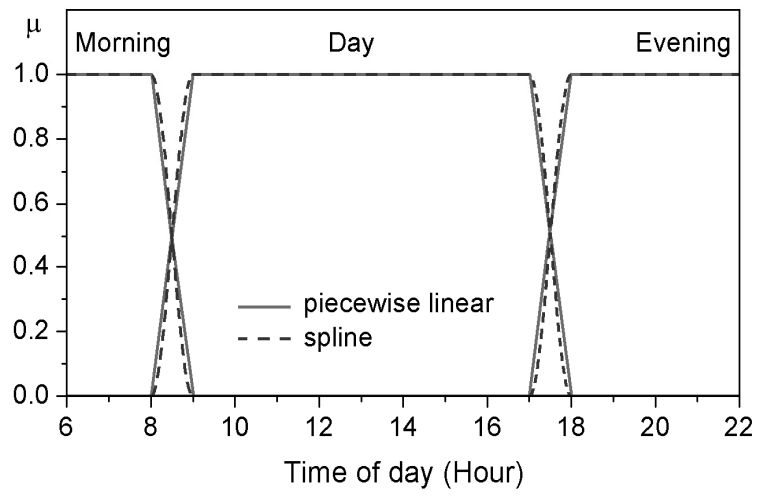

b)

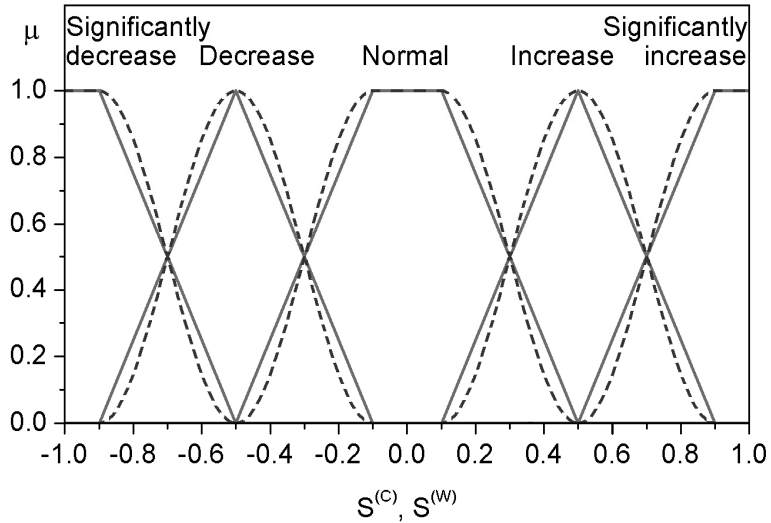

c)
Fig. 2. Membership functions of fuzzy sets describing the input variables "intensity of natural light" (a) "time of day" $(b)$ and output variables that reflect the control signal of "cold" $S^{(C)}$ and "warm" $S^{(W)}$ light $(c)$

The truth of the conclusions of each production rule was determined using the procedure min-activation or prod-activation of conclusions [17]. Moreover only active rules of fuzzy productions were taken into account, that is, the degree of truth conditions of which is different from zero.

Accumulation of conclusions of production rules was carried out by max-aggregation of fuzzy sets that respond to terms of found conclusions for the corresponding output variables. Defuzzification of output variables was carried out by the Centre of Gravity method [18].

\section{Results and Discussion}

Test results of the automated lighting control system based on fuzzy inference are illustrated in Fig. 3, which shows the dependence of the output control signals of "cold" $S^{(C)}$ and "warm" $S^{(W)}$ light systems on natural light and time of day.

Setting of the output linguistic variables $S^{(C)}$ and $S^{(W)}$ on the set $[-1,1]$ allows to get the value of the output signals as a percentage of maximum windows transparency $T_{\max }$ and maximum power of "cold" $P^{(C)}{ }_{\max }$ and "warm" $P^{(W)}{ }_{\max }$ light sources needed for optimal illumination of a particular room. This approach is versatile for rooms different in size and shape, with various reflective properties of the walls, for smart windows different in size and type, for LED or fluorescent light sources.

Control signals determine the power of sources of "cold" $P^{(C)}$ and "warm" $P^{(W)}$ light at $y_{1}, y_{2} \in[0,1]$ or the transparency of windows $T$ at $y_{1}, y_{2} \in[-1,0]$ :

$$
\begin{aligned}
& P^{(C)}=\left\{\begin{array}{ccc}
0 & y_{1} \in[-1,0] & x_{2} \in[8,18], \\
y_{1} k_{1} P_{\max }^{(C)} & y_{1} \in(0,1] & x_{2} \in[8,18]
\end{array}\right. \\
& P^{(W)}=\left\{\begin{array}{ccc}
0 & y_{2} \in[-1,0] & x_{2} \in[6,9] \cup[17,22], \\
y_{2} k_{2} P_{\max }^{(W)} & y_{2} \in(0,1] & x_{2} \in[6,9] \cup[17,22]
\end{array},\right. \\
& T=\left\{\begin{array}{cc}
\left(1+\max \left\{y_{1}, y_{2}\right\}\right) T_{\max } & y_{1}, y_{2} \in[-1,0), \\
1 & y_{1}, y_{2} \in[0,1]
\end{array}\right.
\end{aligned}
$$

where the coefficients $k_{1}$ and $k_{2}$ allow to take into account the contribution of cold and warm light sources to obtain the necessary lighting level

$$
k_{1}=\frac{y_{1}}{y_{1}+y_{2}},
$$




$$
k_{2}=\frac{y_{2}}{y_{1}+y_{2}} .
$$

Calculations show that the fuzzy logic controller provides increased power of artificial light sources while reducing the intensity of natural light, moreover in the daytime cold lighting system is involved, and in the morning and evening - warm lighting system. In the case of intense illumination one observes negative values of control signals regardless of time of day, providing reduction in the smart windows transmission coefficient (see Fig. 3).

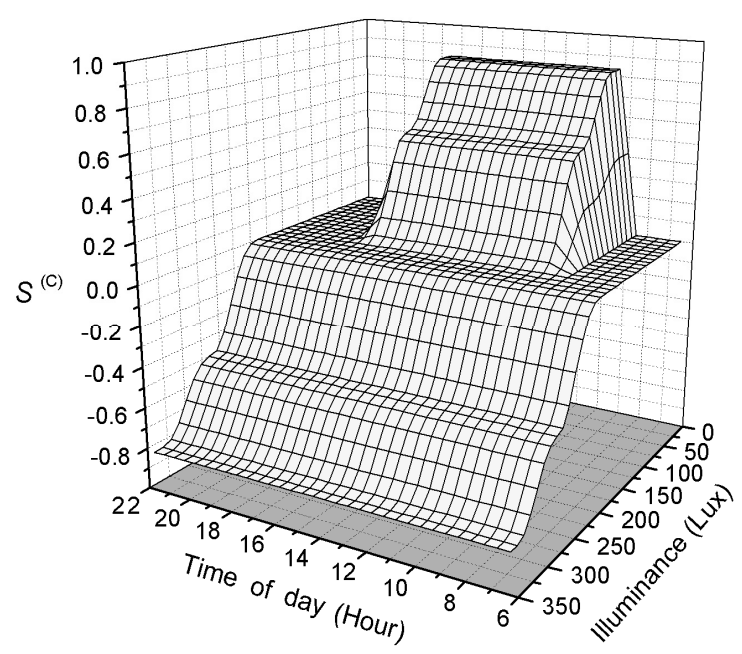

a)

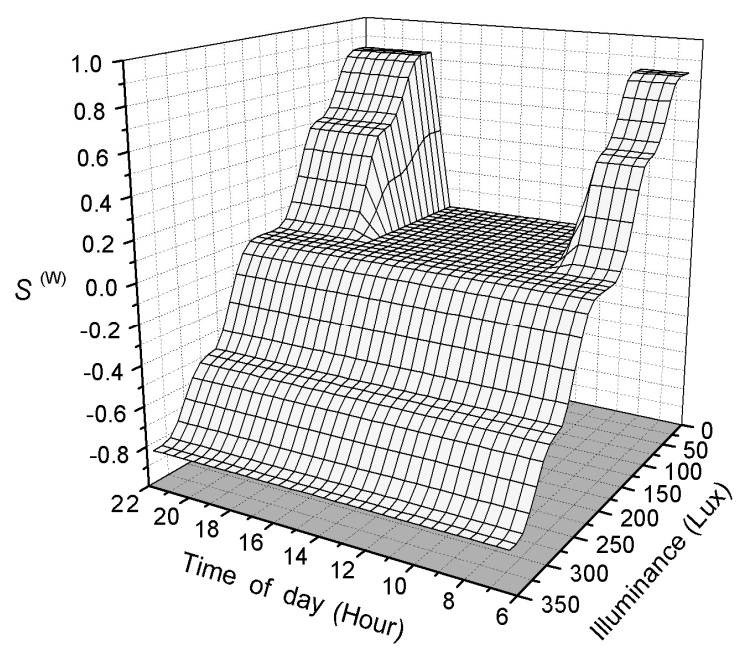

b)

Fig. 3. Dependence of control signals of "cold" $S^{(C)}(a)$ and "warm" $S^{(W)}(b)$ lighting systems on natural light and time of day

It should be noted that the use of spline functions for setting membership functions of fuzzy sets leads to a smoother shift of output control signal when changing the light intensity compared with piecewise linear functions (Fig. 4).

In addition, the choice of activating conclusions of fuzzy production affects the character of dependence of the output control signal on the light intensity. In particular, the use of min-activation or prod-activation of conclusions shows different sensitivity of the lighting control systems based on fuzzy logic controller in different ranges of deviation of natural light from optimal values. This allows taking into account the individual characteristics of residents to create comfortable living conditions.

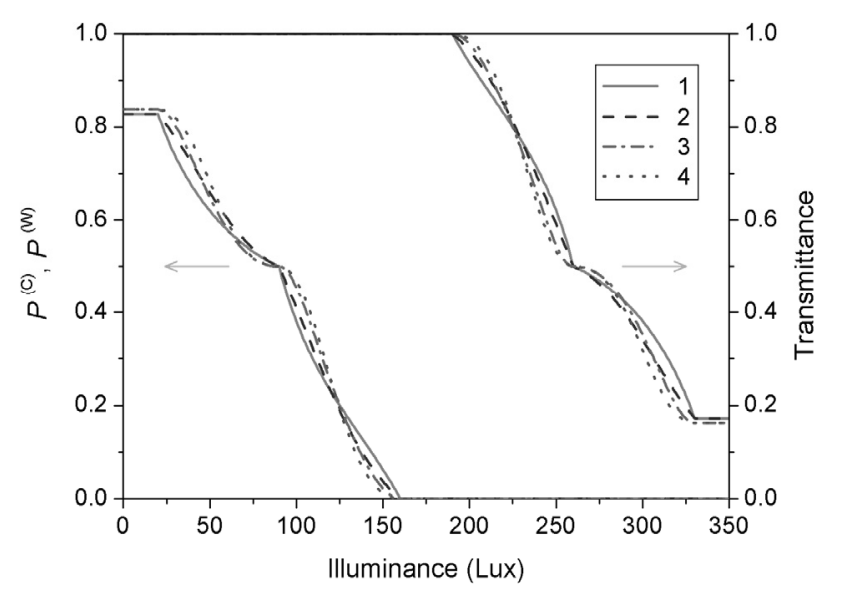

Fig. 4. The dependence of the output variables of lighting control system on natural light in the case of piecewise linear functions $(1,2)$ and spline functions $(3,4)$ and min-activation $(1,3)$ and prod-activation $(2,4)$ of conclusions

\section{Conclusions}

Thus, the considered lighting control method in buildings based on fuzzy logic controller enables to get the quantitative values of power of light sources with different spectral characteristics and output signal that controls the windows transparency for current values of natural light and time of day. The proposed algorithm does not require complicated calculations. This leads to simplification of lighting control in intelligent houses.

The obtained results show that using piecewise linear or spline functions for setting fuzzy sets and minor prod-activation of production rules conclusions allows changing the sensitivity of the control system in different ranges of deviation of natural light from the norm.

\section{References}

1. Mendes T.D.P., Godina R., Rodrigues E.M.G., Matias J.C.O., Catalao J.P.S. Smart home communication technologies and applications: wireless 
protocol assessment for home area network resources // Energies. - 2015. - Vol. 8. - P. 7279-7311.

2. Harper R. Inside the Smart Home. - London: Springer, 2003.

3. Zhang D., Shah N., Papageorgiou L.G. Efficient energy consumption and operation management in a smart building with microgrid // Energy Conversion and Management. - 2013. - Vol. 74. - P. 209-222.

4. Robles R.J., Kim T.-H. Applications, systems and methods in smart home technology: A review // International Journal of Advanced Science and Technology. - 2010. - Vol. 15. - P. 37-47.

5. Pan M.S., Yeh L.W., Chen Y.A., Lin Y.H., Tseng Y.C. A wsn-based intelligent light control system considering user activities and profiles // IEEE Sensors Journal. - 2008. - Vol. 8. - P. 1710-1721.

6. Mohamaddoust R., Haghighat A.T., Sharif M.J.M., Capanni N. A novel design of an automatic lighting control system for a wireless sensor network with increased sensor lifetime and reduced sensor numbers // Sensors. - 2011. - Vol. 11. - P. 8933-8952.

7. Baetens R., Jelle B.P., Gustaven A. Properties, requirements and possibilities of smart windows for dynamic daylight and solar energy control in buildings: A state-of-the-art review // Solar Energy Materials and Solar Cells. - 2010. - Vol. 94. - P. 87-105.

8. Vergaz R., Pena J.M.S., Barrios D., Perez I., Torres J.C. Electrooptical behaviour and control of a suspended particle device // Opto-Electronics Review. 2007. - Vol. 15. - P. 154-158.

9. Olenych I.B., Aksimentyeva O.I., Monastyrskii L.S., Pavlyk M.R. Electrochromic effect in photoluminescent porous silicon-polyaniline hybrid structures // Journal of Applied Spectroscopy. - 2012. Vol. 79. - P. 495-498.
10. Jin M.-L., Ho M.-C. Labview-based fuzzy controller design of a lighting control system // Journal of Marine Science and Technology. - 2009. - Vol. 17. - P. 116-121.

11. Panjaitan S.D., Hartoyo A. A lighting control system in buildings based on fuzzy logic // Telkomnika. - 2011. - Vol. 9. - P. 423-432.

12. Saravanan K., Prabhu N.M., Rajeswari B.R. Fuzzy controller design of lighting control system by using VI package // International Journal of Scientific and Research Publications. - 2014. - Vol. 4. - P. 1-6.

13. Zadeh L.A. Fuzzy sets // Information and Control. - 1965. - Vol. 8. - P. 338-353.

14. Kumar V., Kumar S., Kansal H. Fuzzy logic controller based operating room air condition control system // International Journal of Innovative Research in Electrical, Electronics, Instrumentation and Control Engineering. - 2014. - Vol. 2. - P. 510-514.

15. Sobhy S.M., Khedr W.M. Developing of fuzzy logic controller for air condition system // International Journal of Computer Applications. - 2015. - Vol. 126. - P. 1-8.

16. Mamdani E.H. Application of fuzzy algorithms for the control of a simple dynamic plant // Proceedings of the Institution of Electrical Engineers. - 1974. - Vol. 121. - P. 1585-1588.

17. Besedin P.V., Andrushhak S.V., Kozlov V.K. Fuzzy inference technique in the task of sludge batching management // International Journal of Soft Computing. - 2015. - Vol. 10. - P. 415-419.

18. Bai Y., Wang D. Fundamentals of fuzzy logic control - fuzzy sets, fuzzy rules and defuzzifications. Advanced Fuzzy Logic Technologies in Industrial Applications. - Springer, 2006.

Received in final form on 26 December 2016 
Оленич I.В.

Контролер нечіткої логіки для системи керування освітленням розумного будинку

Проблематика. Сучасні високотехнологічні системи автоматизації будинку здатні без участі людини забезпечувати продуктивне та ефективне керування функціями розумного будинку. Для комфортного перебування в приміщенні ці системи повинні забезпечувати контроль температури, рівня освітленості, вологості та забруднення повітря. Зокрема, контролер нечіткої логіки перспективний для застосування в інтелектуальних системах керування освітленням.

Мета. Розробка двоканальної системи керування освітленням розумного будинку, яка забезпечує контроль не тільки потужності джерел світла, але і їх спектральних характеристик.

Методика реалізації. Система керування освітленням на основі нечіткого логічного висновку передбачає формування бази нечітких продукційних правил, фазифікацію вхідних значень, агрегацію істинності підумов кожного 3 правил, активізацію висновків i процедуру дефазифікації, яка формує вихідний сигнал для керування функціональними пристроями розумного будинку.

Результати досліджень. У результаті представлення різнотипних вхідних даних за допомогою лінгвістичних змінних і закладених у базі нечітких продукційних правил для поточних значень природного освітлення і часу доби отримано кількісні значення потужності джерел світла з різними спектральними характеристиками та вихідний сигнал, який керує прозорістю вікон. Показано можливість змінювати чутливість системи керування в різних діапазонах відхилення освітлення від оптимальних значень.

Висновки. Спосіб керування освітленням приміщень на основі контролера нечіткої логіки дає змогу отримати кількісні значення потужності джерел світла з різними спектральними характеристиками, враховуючи індивідуальні особливості мешканців.

Ключові слова: керування освітленням, контролер нечіткої логіки, продукційні правила, нечіткі множини, активація висновків.

\section{Оленич И.Б.}

Контроллер нечеткой логики для системы управления освещением умного дома

Проблематика. Современные высокотехнологичные системы автоматизации дома способны без участия человека обеспечивать продуктивное и эффективное управление функциями умного дома. Для комфортного пребывания в помещении эти системы должны обеспечивать контроль температуры, уровня освещенности, влажности и загрязнения воздуха. В частности, контроллер нечеткой логики перспективен для применения в интеллектуальных системах управления освещением.

Цель исследований. Разработка двухканальной системы управления освещением умного дома, которая обеспечивает контроль не только мощности источников света, но и их спектральных характеристик.

Методика реализации. Система управления освещением на основе нечеткого логического вывода предусматривает формирование базы нечетких продукционных правил, фаззификацию входных значений, агрегацию истинности подусловий каждого из правил, активизацию выводов и процедуру дефаззификации, которая формирует выходной сигнал для управления функциональными устройствами умного дома.

Результаты исследований. В результате представления разнотипных входных данных с помощью лингвистических переменных и заложенных в базе нечетких продукционных правил для текущих значений естественного освещения и времени суток получены количественные значения мощности источников света с различными спектральными характеристиками и выходной сигнал, который управляет прозрачностью окон. Показана возможность изменения чувствительности системы управления в различных диапазонах отклонения освещения от оптимальных значений.

Выводы. Способ управления освещением помещений на основе контроллера нечеткой логики позволяет получить количественные значения мощности источников света с различными спектральными характеристиками, учитывая индивидуальные особенности жителей.

Ключевые слова: управление освещением, контроллер нечеткой логики, продукционные правила, нечеткие множества, активация выводов. 